\title{
PROFIL KETAHANAN PANGAN KABUPATEN JEMBRANA 2017
}

\author{
Hertog Nursanyoto, Ni Komang Wiardani, A.A. Ngurah Kusumajaya \\ Dosen Jurusan Gizi Poltekkes Denpasar \\ HertogNursanyoto@gmail.com
}

\begin{abstract}
The agricultural and plantation sectors are still the main economic support in Jembrana. Potential commodities that include coconut, coffee, cloves, cacao, and vanilla. Although Jembrana has been known as plentiful food production area, but food security study in Jembrana never done. This research is a cross sectional study conducted for 6 months in 10 selected villages namely Warnasari and Tuwed villages in Melaya; Tegal Badeng Barat and Baler Bale Agung in the Negara; Budeng and Yeh Kuning in Jembrana; Pohsanten and Delod Berawah in Mendoyo; and also Gumrih and Pulukan in Pekutatan. From each village was selected by simple random sampling of 20 households to obtain the total sample as a whole, amounting to200 households. From the result, it is known that the energy accessibility of Jembrana population reach $3669,64 \mathrm{kcal} /$ capitalday, or about 166,8\% AKE. As for the accessibility of protein reached $160,96 \mathrm{~g} /$ capita/day or nearly three-fold $(282.39 \%$ AKP). The energy consumption is $2174,37 \mathrm{kcal} / \mathrm{capita}$ day $(101,13 \%$ AKE). While the protein consumption was $71.65 \mathrm{~g} /$ capita/day (125,7\% PPA) with an average food desirable pattern score (PPH) of 90,06. It can be concluded that the food consumption pattern of Jembrana Regency in 2017 quantitatively has been good, but qualitatively still not fulfill the national target. Some current problems and possibilities that occur in the future namely: a) The energy consumption, and especially the protein consumption of Jembrana district in 2017 has exceeded; b) Food security study is necessary every year to monitor the accessibility and level of energy and protein consumption of Jembrana residents.
\end{abstract}

Keywords: Food Security, Level of Conssumption, Food Desirable Pattern

Abstrak. Sektor pertanian dan perladangan masih merupakan sokongan ekonomi utama di Jembrana. Komoditi yang berpotensi termasuk kelapa, kopi, ulas, kakao, dan vanila. Walaupun Jembrana telah dikenal sebagai kawasan penghasil makanan yang berlimpah, namun kajian keamanan makanan di Jembrana tidak pernah dilakukan. Kajian ini adalah satu kajian rentas lintang yang dijalankan selama 6 bulan di 10 kampung terpilih yaitu desa Warnasari dan Tuwed di Melaya; Tegal Badeng Barat dan Baler Bale Agung di Negara; Budeng dan Yeh Kuning di Jembrana; Pohsanten dan Delod Berawah di Mendoyo; dan juga Gumrih dan Pulukan di Pekutatan. Dari setiap kampung dipilih oleh sampling acak sederhana sebanyak 20 isi rumah untuk mendapatkan jumlah sampel secara keseluruhan, berjumlah 200 isi rumah. Hasil penelitian menunjukkan bahwa aksesibilitas energi penduduk Jembrana mencapai 3669,64 kcal / kapita / hari, atau sekitar 166,8\% AKE. Adapun aksesibilitas protein mencapai $160.96 \mathrm{~g} / \mathrm{kapita} / \mathrm{hari}$ atau hampir hampir tiga kali lipat (282.39\% AKP). Penggunaan tenaga ialah $2174.37 \mathrm{kcal} / \mathrm{kapita} / \mathrm{hari}(101.13 \%$ AKE). Walaupun penggunaan protein adalah $71.65 \mathrm{~g} /$ kapita / hari (125.7\% PPA) dengan rata-rata skor pola makanan yang diingini (PPH) sebanyak 90.06. Dapat disimpulkan bahwa pola pemakaian makanan Kabupaten Jembrana pada tahun 2017 secara kuantitatif telah baik, namun secara kualitatif masih belum memenuhi target nasional. Beberapa masalah dan kemungkinan yang berlaku pada masa akan datang iaitu: a) Penggunaan energi, dan terutamanya penggunaan protein di daerah Jembrana pada tahun 2017 telah melebihi; b) Kajian keselamatan makanan perlu dilakukan setiap tahun untuk memantau ketercapaian dan tahap penggunaan energi dan protein penduduk Jembrana.

Kata kunci: Keamanan Makanan, Tingkat Konsumsi, Pola Pangan Harapan 


\section{Pendahuluan}

Pangan sebagai sumber zat gizi bagi manusia merupakan kebutuhan pokok yang harus dipenuhi setiap hari untuk dapat mempertahankan hidup. Berdasarkan Undang - Undang No 18 tahun 2012 bahkan ditegaskan bahwa pangan merupakan kebutuhan dasar manusia yang paling utama dan pemenuhannya merupakan bagian dari hak asasi manusia yang dijamin di dalam Undang-Undang Dasar Negara Republik Indonesia tahun 1945 sebagai komponen dasar untuk mewujudkan sumber daya manusia yang berkualitas. ${ }^{1}$ Berbeda dengan kebutuhan hidup yang lain, kebutuhan pangan hanya diperlukan secukupnya. Kekurangan maupun kelebihan konsumsi pangan, terutama apabila dialami dalam jangka waktu lama, akan berdampak buruk pada kesehatan. Perkembangan masalah gizi ganda (double burden malnutrition) dimana masalah kekurangan dan kelebihan gizi terjadi pada saat bersamaan juga sudah menunjukkan angka signifikans di Indonesia. Hasil Survei Kesehatan Rumah Tangga yang mewakili $85 \%$ penduduk Indonesia menunjukkan kecenderungan peningkatan jumlah orang gemuk hampir dua kali lipat dari periode sebelumnya, sementara jumlah orang kurus masih menunjukkan angka yang bermakna pada periode yang sama. $^{2}$

Situasi ketahanan pangan di Indonesia belum begitu kuat. Hal ini antara lain ditandai dengan masih tingginya jumlah penduduk/wilayah yang mengalami rawan pangan. Kerawanan pangan dapat diketahui dari tingkat kecukupan konsumsi zat gizi masyarakat yang diukur dari Angka Kecukupan Gizi (AKG). AKG merupakan tingkat konsumsi zat-zat gizi esensial yang dinilai cukup untuk memenuhi kebutuhan gizi hampir semua orang sehat di suatu negara. AKG adalah istilah yang digunakan untuk Indonesia, di negara lain seperti di Amerika digunakan istilah Recommended Dietary Allowance (RDA), yang merupakan standar yang berisi kebutuhan rata-rata zat gizi per hari yang dianjurkan sehingga suatu masyarakat dapat hidup sehat. Di Canada istilah yang digunakan adalah Recommended Nutrient Intake atau RNI. ${ }^{3}$ AKG diperoleh dari data Susenas BPS yang dikumpulkan setiap triwulan dalam tahun. Angka kecukupan rata-rata konsumsi energi penduduk Indonesia per kapita per hari berdasarkan Widyakarya Nasional Pangan dan Gizi XI (WNPG) 2013 adalah 2150 kkal. Persentase rawan pangan berdasar angka kecukupan gizi (AKG) suatu daerah, dihitung dengan menjumlahkan penduduk dengan 
konsumsi kalori kurang dari 1500 kkal (70\% AKG) perkapita dibagi dengan jumlah penduduk pada golongan pengeluaran tertentu. Berdasarkan laporan Persentase Angka Rawan Pangan Tahun 2008-2012 yang dirilis BPS, diperoleh bahwa pada 2012 ternyata masih terdapat 47,64 juta penduduk atau 19,46 persen dari seluruh penduduk di Indonesia yang mengalami kondisi sangat rawan. ${ }^{4}$

Perlu ditegaskan di sini bahwa permasalahan dan tantangan untuk mewujudkan ketahanan pangan Indonesia berkelanjutan bersifat multidimensi, mencakup aspek ekonomi, sosial, politik, dan lingkungan. Indentifikasi permasalahan dan tantangan tersebut dapat dilakukan melalui analisis penawaran dan permintaan pangan. Dari sisi penawaran, tantangan tersebut di antaranya berupa persaingan pemanfaatan sumber daya alam, dampak perubahan iklim global, dan dominasi usahatani skala kecil. Dari sisi permintaan, di antara tantangan tersebut adalah pertumbuhan penduduk yang tinggi beserta dinamika karakteristik demografisnya, perubahan selera konsumen, dan persaingan permintaan komoditas pangan untuk konsumsi manusia, pakan, dan bahan baku energi. Dari hasil kajian yang telah dilakukan dapat disimpulkan bahwa selama lima tahun terakhir secara makro Indonesia mampu menyediakan pangan yang cukup untuk memenuhi kebutuhan warganya, namun kualitas konsumsi pangan rata-rata masyarakat Indonesia masih di bawah rekomendasi para ahli gizi. Berpijak pada fakta ini, maka tantangan menuju ketahanan pangan Indonesia berkelanjutan tahun 2025 akan semakin berat. ${ }^{5}$.

Situasi rawan pangan tentu saja berkaitan erat dengan pangan yang tersedia. Ketersediaan pangan di samping berasal dari produksi dalam negeri dan cadangan pangan nasional juga dapat berasal dari impor apabila kedua sumber utama tersebut tidak dapat memenuhi kebutuhan. Ketahanan pangan merupakan tantangan yang mendapatkan prioritas untuk mencapai kesejahteraan bangsa ini. Upaya mewujudkan ketahanan pangan nasional harus bertumpu pada sumber daya pangan lokal yang mengandung keragaman antar daerah. Menyimak situasi dan kondisi terkini di Indonesia, permasalah pangan memang tidak dapat di hindari. Walaupun Indonesia sering disebut sebagai negara agararis kenyataannya masih banyak kekurangan pangan yang melanda Indonesia, Bertambahnya penduduk bukan hanya menjadi satu-satunya permasalahan yang menghambat untuk menuju ketahanan pangan nasional. Berkurangnya lahan pertanian yang dikonversi menjadi pemukiman dan lahan industri, telah menjadi ancaman dan tantangan tersendiri 
bagi bangsa Indonesia untuk menjadi bangsa yang mandiri dalam bidang pangan, termasuk belum optimalnya pemanfaatan dan pengelolaan lumbung pangan masyarakat. ${ }^{6}$

Kabupaten Jembrana merupakan wilayah yang terletak ujung Barat Provinsi Bali. Hingga saat ini, sektor pertanian masih menjadi tumpuan perekonomian yang utama di Jembrana. Di samping pertanian, perkebunan juga memiliki kedudukan strategis dalam pembangunan pertanian di Jembrana. Komoditas perkebunan yang potensial dikembangkan dan memiliki peluang ekspor antara lain adalah kelapa, kopi, cengkeh, cacao, dan vanila. Meski dikenal sebagai daerah dengan potensi produksi pangan yang berlimpah, namun sampai saat ini belum pernah dilakukan kajian tentang ketersediaan pangan (energi dan protein), konsumsi pangan (energi dan protein) serta keragaman konsumsi pangan di wilayah Kabupaten Jembrana. Atas dasar inilah maka dipandang perlu untuk melakukan kajian terhadap ketersediaan pangan (energi dan protein) tahun 2016 -2017, keragaman konsumsi pangan melalui pola pangan harapan serta tingkat konsumsi energi dan protein rata-rata rumah tangga penduduk Kabupaten Jembrana tahun $2016 .{ }^{7}$

\section{Metode}

Penelitian tentang Kajian/Analisis

Pola Konsumsi Pangan Kabupaten Jembrana tahun 2017 merupakan penelitian observasional karena peneliti hanya melakukan kegiatan pengamatan tanpa disertai intervensi apapun terhadap subyek penelitian. Sedangkan rancangan penelitian termqasuk sebagai rancangan cross sectional karena penelitian ini merupakan penelitian single variable yang bermaksud menggambarkan profil ketahanan pangan di suatu wilayah. Penelitian dilaksanakan di wilayah Kabupaten Jembrana selama enam bulan, dari bulan Juni sampai dengan November 2017.Sampel penelitian untuk pola konsumsi pangan rumah tangga ditentukan secara purposive, yaitu akan dipilih sebanyak 20 rumah tangga (RT) per desa yang terpilih sebagai lokasi penelitian. Pengambilan sampel ditentukan secara acak bertingkat, yaitu setiap kecamatan dipilih dua desa. Berdasarkan hasil pengacakan yang dilakukan, desa terpilih untuk lokasi penelitian adalah Desa Warnasari dan Tuwed di Kecamatan Melaya; Desa Tegal Badeng Barat dan Baler Bale Agung di Kecamatan Negara; Desa Budeng dan Yeh Kuning di Kecamatan Jembrana; Desa Pohsanten dan Delod Berawah di Kecamatan Mendoyo; dan Desa Gumrih dan Pulukan di Kecamatan Pekutatan. Dari masingmasing desa kemudian dipilih satu banjar, 
dan masing-masing banjar dipilih secara acak sederhana 20 rumah tangga sehingga diperoleh total sampel secara keseluruhan adalah berjumlah 200 rumah tangga. Data yang diambil data penelitian ini meliputi data primer yaitu identitas keluarga dan tingkat konsumsi energi dan protein keluarga, serta data sekunder yaitu produksi pangan kabupaten Jembrana 2016. Tingkat Konsumsi Energi dan Protein Keluarga akan diolah menjadi gambaran Pola Pangan Harapan (PPH). Konsep PPH pertama kali diperkenalkan oleh FAO RAPA (Regional office of Asia and Pasific) pada tahun 1989. PPH menilai mutu konsumsi penduduk dengan pendekatan skor, dimana semakin tinggi skor yang diperoleh maka akan semakin menunjukkan situasi pangan yang semakin beragam dan tinggi mutu gizinya. ${ }^{8}$ Sedangkan Produksi Pangan akan diolah menjadi data ketersediaan pangan Kabupaten Jembrana. Pengertian tersedia untuk dikonsumsi penduduk disini adalah yang tersedia di tingkat pedagang eceran atau yang tersedia di rumah para konsumen. 9 Dari kedua gambaran hasil pengolahan inilah akan diketahui kondisi Ketahanan Pangan di Kabupaten Jembrana.

\section{Hasil dan Pembahasan}

Ketersediaan Energi dan Protein

Seperti tersaji pada gambar 1 diketahui bahwa ketersediaan energi penduduk Kabupaten Jembrana 2016 mencapai 3.669,64 kkal/ kapita/ hari, atau sekitar 166,8\% apabila dibandingkan dengan angka kecukupan energi (AKE) pada tingkat ketersediaan yaitu sebesar $2.200 \mathrm{kkal} / \mathrm{kapita} / \mathrm{hari}$. Sedangkan untuk protein ketersediaannya mencapai 160,96 g/ kapita/ hari atau mendekati hampir tiga kali lipat $(282,39 \%)$ terhadap angka kecukupan protein (AKP) pada tingkat ketersediaanyaitu sebesar $57 \mathrm{~g} / \mathrm{kapita} / \mathrm{hari}$.

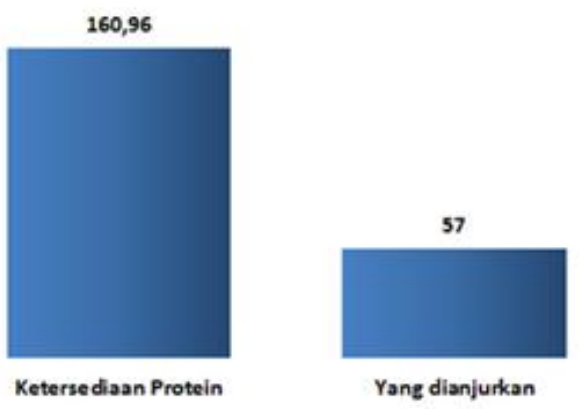

Gambar 1

Ketersediaan Energi dan Protein Kabupaten Jembrana 2016 
Apabila diperhatikan kontribusi energi menurut sumber masing - masing bahan makanan, terdapat empat kelompok bahan makanan yang memiliki kontribusi sangat nyata terhadap surplus ketersediaan pangan di Kabupaten Jembrana yaitu (1) produksi daging dengan total kontribusi energi sebesar 1.346,28 kkal/kapita/hari $(61,19$ dari ketersediaan yang dianjurkan\%); (2) produksi padi - padian dengan total kontribusi energi sebesar
1.151,47 kkal/kapita/hari (53,24\%); (3) produksi minyak dan lemak dengan total kontribusi sebesar 535,96 kkal/kapita/hari (24,36\%); dan (4) produksi buah dan biji berminyak dengan total kontribusi sebesar 446,8 kkal/kapita/hari (20,31\%). Secara rinci kontribusi energi pada masingmasing bahan makanan berdasarkan hasil analisis NBM Kabupaten Jembrana tahun 2016 dapat dilihat pada Tabel 1.

Tabel 1

Kontribusi Energi Menurut Kelompok Bahan Makanan

Kabupaten Jembrana Tahun 2016

\begin{tabular}{rlrr}
\hline No & \multicolumn{1}{c}{ BahanMakanan } & $\begin{array}{c}\text { Energi } \\
\text { (kkal/kap/hari) }\end{array}$ & $\begin{array}{c}\% \\
\text { Ketersediaan }\end{array}$ \\
\hline 1 & Padi-padian & $1.151,47$ & 52,34 \\
2 & MakananBerpati & 2,22 & 0,10 \\
3 & Gula & 0,00 & 0,00 \\
4 & Buah/bijiberminyak & 446,80 & 20,31 \\
5 & Buah-buahan & 19,44 & 0,88 \\
6 & Sayuran & 0,00 & 0,00 \\
7 & Daging & $1.346,28$ & 61,19 \\
8 & Telur & 14,72 & 0,67 \\
9 & Susu & 0,00 & 0,00 \\
10 & Ikan & 152,73 & 6,94 \\
11 & Minyakdanlemak & 535,96 & 24,36 \\
\hline \multicolumn{2}{c}{ Jumlah } & $3.669,64$ & 166,80 \\
\hline
\end{tabular}

Sedangkan untuk kontribusi protein masing - masing kelompok bahan makanan, maka kontribusi protein dari hasil produksi daging saja sudah melampaui bahkan lebih dari tiga kali lipat $(156,57 \%)$ dibandingkan tingkat ketersediaanyang dianjurkan sebesar 57 g/kapita/hari. Kelompok bahan makanan lain yang memberi kontribusi nyata surplus protein di kabupaten Jembrana adalah produksi ikan yang mencapai 29,01 g/kapita/hari atau mencapai 50,9\% dari 
total protein pada tingkat persediaan; produksi padi - padian yang mencapai $28,25 \mathrm{~g} / \mathrm{kapita} / \mathrm{hari}$ atau mencapai $49,56 \%$ dari total protein pada tingkat persediaan; serta produksi buah dan biji berminyak yang mencapai $122,55 \mathrm{~g} / \mathrm{kapita} / \mathrm{hari}$ atau mencapai $22,01 \%$ dari total protein pada tingkat persediaan sebesar 57\%. Secara rinci kontribusi proteinpada masingmasing bahan makanan berdasarkan hasil analisis NBM Kabupaten Jembrana tahun 2016 dapat dilihat pada Tabel 2.

Tabel 2

Kontribusi Protein Menurut Kelompok Bahan Makanan Kabupaten Jembrana tahun 2016

\begin{tabular}{clrr}
\hline No & \multicolumn{1}{c}{ BahanMakanan } & $\begin{array}{c}\text { Protein } \\
(\mathrm{g} / \text { kap/hari })\end{array}$ & $\begin{array}{c}\% \\
\text { Ketersediaan }\end{array}$ \\
\hline 1 & Padi-padian & 28,25 & 49,56 \\
2 & MakananBerpati & 0,01 & 0,03 \\
3 & Gula & 0,00 & 0,00 \\
4 & Buah/bijiberminyak & 12,55 & 22,01 \\
5 & Buah-buahan & 0,23 & 0,40 \\
6 & Sayuran & 0,00 & 0,00 \\
7 & Daging & 89,25 & 156,57 \\
8 & Telur & 1,05 & 1,85 \\
9 & Susu & 0,00 & 0,00 \\
10 & Ikan & 29,01 & 50,90 \\
11 & Minyakdanlemak & 0,62 & 1,08 \\
\hline \multicolumn{4}{c}{ Jumlah } \\
\hline
\end{tabular}

Dengan tingkat surplus produksi yang mencapai hampir dua kali lipat dibanding angka yang dianjurkan dapat disimpulkan bahwa Kabupaten Jembrana memang merupakan salah satu sentra produksi pangan di Provinsi Bali.

\section{Konsumsi Energi dan Protein}

Konsumsi energi rata - ratarumah tangga adalah 2174,37 kkal/kapita/hari.
Angka ini telahmelebihi AKE yang dianjurkan yaitu sebesar 2.150 $\mathrm{kkal} / \mathrm{kapita} / \mathrm{hari}$ atau sekitar 101,13\% terhadap AKE. Sedangkan konsumsi protein rata - ratarumah tangga adalah $71,65 \mathrm{~g} / \mathrm{kapita} / \mathrm{hari}$ yang berarti sudah melampauiAKP yang dianjurkan yaitu sebesar 57g/kapita/hari atau sekitar 125,7\% terhadap AKP. Untuk lebih jelasnya dapat dilihat pada gambar 2 . 


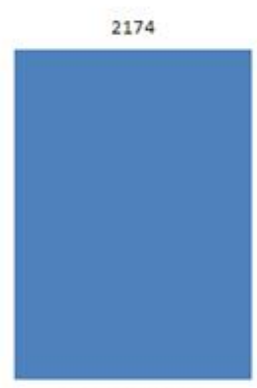

Konsumsi Energi

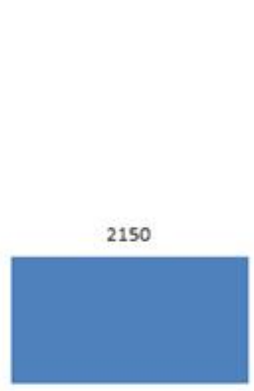

AKE

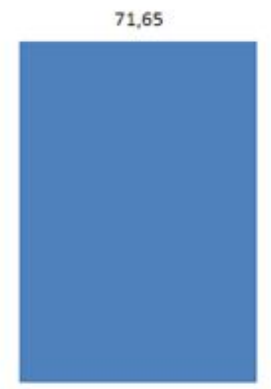

Konsumsi Prote in

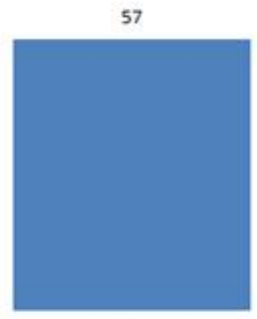

AKP

Gambar 2

Tingkat Konsumsi Energi dan Protein Dibandingkan Angka Kecukupan Yang Dianjurkan pada Rumah Tangga di Kabupaten Jembrana 2017

Berdasarkan deskripsi tingkat konsumsi energi dan protein seperti tersaji pada gambar 2 maka dapat disimpulkan bahwa Kabupaten Jembrana berada dalam situasi normal dan tidak mengalami masalah rawan pangan.

\section{Pola Pangan Harapan}

Skor pola pangan harapan $(\mathrm{PPH})$ rata-rata rumah tangga Kabupaten Jembrana 2017 adalah 90,06. Dari gambaran pola konsumsi ini dapat disimpulkan bahwa pola konsumsi pangan rumah tangga Kabupaten Jembrana tahun 2017 secara kuantitatif sudah memenuhi angka kecukupan gizi yang dianjurkan baik AKE maupun AKP, namun secara kualitatif masih belum memenuhi target nasional skor PPH yang ditetapkan dengan skor 93. Hal ini terjadi karena kelompok bahan yang paling banyak berkontribusi pada pemenuhan energi hanyalah padi padian, protein hewani dan kacang kacangan. Sementara kelompok bahan makanan lainnya yaitu kelompok umbi umbian, sayur, dan buah yang memiliki kontribusi energi relatif masih sangat kecil. Gambaran skor PPH selengkapnya disajikan pada tabel 3 . 
Tabel 3

Kontribusi Energi dan Skor PPH Menurut Bahan Makanan Hasil Survei Ketahanan Pangan Kabupaten Jembrana Tahun 2017

\begin{tabular}{lrrrrrrr}
\hline \multirow{1}{*}{\multicolumn{1}{c}{ Bahan Makanan }} & \multicolumn{7}{c}{ Komposisi PPH } \\
\cline { 2 - 8 } & $\begin{array}{c}\text { Energi } \\
\text { g/kap/hr }\end{array}$ & $\begin{array}{c}\text { AKE } \\
\text { A }\end{array}$ & Bobot & $\begin{array}{c}\text { Skor } \\
\text { AKE }\end{array}$ & $\begin{array}{c}\text { Skor } \\
\text { Standar }\end{array}$ & $\begin{array}{c}\text { Skor } \\
\text { PPH }\end{array}$ \\
\hline Padi-padian & 1345,74 & 62,59 & 0,5 & 31,30 & 25 & 25,00 \\
\hline Umbi-umbian & 23,74 & 1,10 & 0,5 & 0,55 & 2,5 & 0,55 \\
Pangan hewani & 285,78 & 13,29 & 2 & 26,58 & 24 & 24,00 \\
Minyak dan lemak & 177,01 & 8,23 & 0,5 & 4,12 & 5 & 4,12 \\
Buah dan biji berminyak & 29,35 & 1,37 & 0,5 & 0,68 & 1 & 0,68 \\
Kacang-kacangan & 134,31 & 6,25 & 2 & 12,49 & 10 & 10,00 \\
\hline Gula & 75,41 & 3,51 & 0,5 & 1,75 & 2,5 & 1,75 \\
Sayuran dan Buah & 103,02 & 4,79 & 5 & 23,96 & 30 & 23,96 \\
\hline \multicolumn{1}{c}{ Jumlah } & $2.174,37$ & 101,13 & & & & $\mathbf{9 0 , 0 6}$ \\
\hline
\end{tabular}

Seperti tersaji pada tabel 3 , konsumsi energi rata - rata penduduk Kabupaten Jembrana sudah memenuhi anjuran kecukupan energi (AKE) dengan tingkat konsumsi mencapai 101,13\%. Bila dilihat berdasarkan kontribusi energi pada masing - masing kelompok bahan makanan, terdapat tiga kelompok bahan yang prosentase energinya telah melampaui angka standar yang ditetapkan dalam penentuan skor pola pangan harapan (PPH) yaitu kelompok padi - padian $(31,3 \%$ dari seharusnya $25 \%)$; protein hewani $(26,58 \%$ dari seharusnya $24 \%)$ dan kacang - kacangan $(12,49 \%$ dari seharusnya 10\%). Sedangkan kelompok bahan makanan yang prosentase energinya belum mencapai angka standar yang ditetapkan terdapat sebanyak lima kelompok yaitu kelompok umbi - umbian $(0,55 \%$ dari seharusnya $2,5 \%)$; minyak dan lemak $(4,12 \%$ dari seharusnya $5 \%)$; buah dan biji berminyak $(0,68 \%$ dari seharusnya $1 \%)$; gula $(1,75 \%$ dari seharusnya $2,5 \%)$; serta sayur dan buah $(23,96 \%$ dari seharusnya 30\%). Dari gambaran susunan skor PPH ini maka dapat disimpulkan bahwa pemenuhan kebutuhan energi rata rata penduduk Kabupaten Jembrana lebih banyak bertumpu pada konsumsi padi padian dan protein hewani, tapi kurang mengkonsumsi umbi - umbian, sayur, dan buah. 


\section{Simpulan dan Saran}

Berdasarkan hasil survei ditemukan beberapa permasalahan saat ini dan kemungkinan yang terjadi di masa yang akan datang yaitu: a) Tingkat konsumsi energi, dan terlebih khusus tingkat konsumsi protein rata-rata rumah penduduk Kabupaten Jembrana 2017 sudah melebihi angka kecukupan yang dianjurkan. Melihat kecenderungan maka disarankan untuk melakukan pemantauan dan pengendalian konsumsi pangan penduduk agar terhindar dari kemungkinan terjadinya masalah gizi lebih (obesitas). Apalagi pola konsumsi penduduk Kabupaten Jembrana menunjukkan kecenderungan yang berisiko, karena terlalu banyak mengkonsumsi padi-padian dan pangan hewani, tapi di sisi lain kurang mengkonsumsi umbi - umbian, sayuran, dan buah - buahan; dan b) Penyusunan NBM sangat perlu dilakukan setiap tahun untuk memonitor ketersediaan dan tingkat konsumsi energi dan protein penduduk Kabupaten Jembrana. Hal ini bermanfaat sebagai system isyarat dini untuk mendeteksi kerawanan pangan yang terjadi yang mungkin saja dapat terjadi apabila dihadapkan pada situasi bencana atau gagal panen.

\section{Daftar Pustaka}

1. Presiden RI. Undang - undang Republik Indonesia Nomor 18 tahun 2012 tentang Pangan. Jakarta : Kementerian Hukum dan HAM RI, 2012.

2. Bank Dunia. Indonesia Menghadapi Beban Ganda Malnutrisi. Jakarta : Indoneisa Health Sector Review, 2012.

3. Sudiarti, T. dan DM Utari. Kecukupan Energi dan Zat Gizi. [book auth.] Departemen Gizi dan Kesehatan Masyarakat FKM-UI. Gizi dan Kesehatan Masyarakat. Jakarta : Raja Grafindo Persada, 2007, pp. 99-131.

4. BPS, RI. Persentase Angka Rawan Pangan Tahun 2008-2012. Jakarta : Biro Pusat Statistik, 2013.

5. Menuju Ketahanan Pangan Indonesia Berkelanjutan 2025: Tantangan dan Penanganannya. Suryana, A. 2, Desember 2014, Forum Penelitian Agro EKonomi, Vol. 32, pp. 123 135.

6. Ketahanan Pangan dan Gizi. Badan Ketahanan Pangan. Jakarta : Persatuan Ahli Gizi Indonesia, 2014. Temu Ilmiah Internasional PERSAGI. pp. 139.

7. BPS Kab Jembrana. Kabupaten Jembrana Dalam Angka 2017. Negara : Biro Pusat Statistik Kabupaten Jembrana, 2017.

8. Planning Desirabe Dietary Pattern for the Future. Khan, MA. 5, 1990, Progressive Farming, Vol. 10, pp. 62 67.

9. FAO. Food Balance Sheet: A Handbook. New York : Food and Agriculture Organization of United Nations, 2008. 